\title{
Protective Role of Grape Seeds Extract against Cadmium Toxicity in the Lung of Male Wistar Rats \\ Baiomy $\mathbf{A A}^{1,2^{*}}$ \\ ${ }^{1}$ Department of Zoology, Faculty of Science, Cairo University, Egypt \\ ${ }^{2}$ Department of Zoology, Faculty of Applied Medical Sciences, Taif University, Airport Rd, Al Huwaya, Saudi Arabia
}

*Corresponding author: Baiomy AA, Department of Zoology, Faculty of Science, Cairo University, Egypt, Tel: +20 1141800984; E-mail: aabdelaziz.baiomy@gmail.com Received date: Jan 08, 2016; Accepted date: Feb 10, 2016; Published date: Feb 12, 2016

Copyright: (c) 2016 Baiomy AA. This is an open-access article distributed under the terms of the Creative Commons Attribution License, which permits unrestricted use, distribution, and reproduction in any medium, provided the original author and source are credited.

\begin{abstract}
Objective: This study was done on 40 male wistar rats to evaluate the curative and protective effect of grape seeds extract on oxidative damage, inflammatory and apoptotic insult on lung tissue induced by cadmium chloride toxicity.

Materials and Methods: The rats were classified to control group (group I), cadmium chloride group (group II), grape seeds extract group (group III) and mixture of grape seeds extract and cadmium chloride group (group IV). At the end of the experimental period, the lungs were collected and fixed in formalin saline (10\%) for histopathological and immunohistochemical studies. Serum samples and frozen lungs were used for biochemical analyses.

Results: The rats groups treated with grape seed showed a significant attenuated oxidative stress by reducing lung tissue malondialdehyde and improving glutathione peroxidase content as well as antioxidant enzymes activities in lung tissues and serum total antioxidant capacity in comparison to group II. The lung tissue of the group II is characterized by thick interalveolar septum, congested and edematous blood vessels. Diffuse and circumscribed lymphocytic infiltration especially around the bronchioles with hyperplasia in the lining cells. Most of the lung tissue showed normal structure as that of the control group except some blood vessels showed congestion in group IV. The immunohistochemical results were negative immunostaining for bcl-2, positive for bax and ki67 in the cadmium treated group, while showed positive immunostaining for bcl-2 in group IV.
\end{abstract}

Conclusion: The addition of grape seeds extract improves the hazard toxic effect of cadmium chloride in the lung tissue through its powerful free radical scavenging property, strong antioxidant activity and effective anti-apoptotic potential.

Keywords: Cadmium; Grape seeds extract; Immunostaining; Bcl-2; Lung

\section{Introduction}

Cadmium $(\mathrm{Cd})$ is a severe toxic element which is widely spread in the environment [1]. Agricultural and industrial activities have given rise to the entry of Cd into the soil and latterly into ground and drinking water. Due to the highly soluble nature of Cd compounds, they are easily taken up by plants resulting in storage in crops for food and feed production [2]. Cadmium is a major component of tobacco due to the hyperaccumulating features of Nicotiana tabacum, which lead to high leaf $\mathrm{Cd}$ concentrations independent of the soil-Cd content [3]. The cadmium concentrates in most of the body organs as lung, brain, testis, kidney, liver and circulatory system [4,5]. It causes pneumonia, respiratory emphysema, interstitial fibrosis and cancer may develop [6].

Cd depletes glutathione and protein-bound sulfhydryl groups, which lead to enhancement of reactive oxygen species generation (ROS) such as superoxide ion, hydroxyl radicals and hydrogen peroxide [7]. Cd acts via oxidative damage to cellular organelles due to its toxicity and its capabilities to induce the generation of (ROS). Next, the reactions of these ROS with cellular biomolecules lead to lipid peroxidation, membrane protein damage, altered anti-oxidant system, DNA damage, altered gene expression and apoptosis [8]. The final results of the cadmium toxicity on the affected cells are apoptosis or necrosis if not balanced by the repair process [9]. Lag et al. [10] revealed that, the Cd-induced apoptosis in the primary cultures of epithelial cells, like alveolar type 2 cells, isolated from rat lung was Bax and p53 dependent, but was independent of oxidative stress pathways. BCL-2 gene family is a group of genes that regulates apoptosis [11]. Many studies proved the correlation between $\mathrm{Cd}$ and cancer induction [12]. KI67 is a nuclear antigen associated with cell proliferation and is presented during the active cell cycle but absent in resting cells [13].

Grape seed extract (GSE) is a natural extract collected from the seed of grape [14]. Grapes and grape products are good sources of dietary flavonoids, which are impressive antioxidant compounds [15]. Moreover, GSE is a complex mixture of polyphenols containing dimers, trimers, and other oligomers of catechin and epicatechin and their gallate derivatives together called the proanthocyanidins [16]. Beyond their antioxidant powers, proanthocyanidins may insulate against atherosclerosis, gastric ulcer, large bowel cancer, cataracts, and diabetes. GSE was also shown to demonstrate cytotoxicity towards human breast, lung, and gastric adenocarcinoma cells [17]. The biological, pharmacological and medicinal properties of the bioflavonoids and proanthocyanidins have been extensively studied 
$[18,19]$. GSE, which is rich with polyphenolic compounds has powerful antimicrobial properties [20-22]. GSE exhibits chemoprotective properties against ROS [23], anti-inflammatory [24] and anti-cancer [25]. Recently, it has been demonstrated that GSE mitigates amiodarone (AM) induced lung injury via its anti-inflammatory and antioxidant activity [26]. Previous studies have presented antiapoptotic effects of GSE in various tissues, including reduction of apoptotic cell death and suppression of proapoptotic proteins [27-29].

The aim of the current study is to evaluate the protective effect of GSE on oxidative damage, inflammatory and apoptotic insult on lung tissue induced by cadmium.

\section{Materials and Methods}

\section{Chemicals}

Cadmium chloride was purchased from Sigma (St. Louis, MO, USA). While GSE was purchased from GNC standard commercial suppliers in Jeddah Saudi Arabia. GSE (formerly Grape Seed PCO Phytosome 50-120 tabs) was obtained from Health Genesis Corp. (Bay Harbor Island, FL, USA).

\section{Animals}

Male wistar rats were purchased from King Fahd experimental center in King Abdul Aziz University Jeddah KSA. All animal procedures were approved by the Ethical Committee office of the Scientific Dean of Taif University, Saudi Arabia.

\section{Experimental design}

Forty male Wistar rats, 3 months old (150-175 g) were used for this study. For acclimatization, animals were kept under observation for 2 weeks before the onset of the experiment. The animals were kept at 12:12-h light-dark cycle and gained free access to food and water. Healthy rats were randomly divided into four groups as follows: Group $\mathrm{I}$, fed on balanced diet and was used as a control for 3 months.

Group II was administered $5 \mathrm{mg}$ cadmium chloride $/ \mathrm{kg}$ body weight/day dissolved in drinking water for 3 months [10].

Group III, was administered $400 \mathrm{mg}$ grape seeds extracts/kg body weight/day dissolved in drinking water for 3 months [29].

Group IV was given mixture (grape seeds extracts diluted in tap water in addition to $5 \mathrm{mg}$ cadmium chloride/day/dissolved in drinking water for 3 months.

At the end of the experimental period, the rats were fasted overnight, subjected to diethyl anaesthesia. The lungs were collected and fixed in formalin saline (10\%) for histopathological and immunohistochemical studies.

\section{Preparation of blood and tissue homogenate}

The blood samples were immediately collected from the overnight fasted rats at the end of the study from the retro orbital venous plexus in the tubes free from any anticoagulant agent for separation of serum samples for biochemical analysis (total antioxidant capacity). The lungs of the rats were homogenized in a four volumes of ice-cold Tris- $\mathrm{HCl}$ buffer (50 millimolar, $\mathrm{pH} 7.4$ ) containing $0.50 \mathrm{ml} / \mathrm{L}$ Triton X-100 with a homogenizer (IKA Ultra-Turrax T 25 Basic, Germany) for 2 minutes at $13000 \mathrm{rpm}$. The homogenate was then centrifuged at $5000 \times \mathrm{g}$ for 20 minutes to remove debris. The supernatant was separated for conducting further biochemical analyses (malondialdehyde, catalase, superoxide dismutase and glutathione peroxidase).

\section{Biochemical analyses}

Lung malondialdehyde (MDA) level was quantified by colorimetric method using lipid peroxide (MDA) assay kit purchased from Biodiagnostic Co., Egypt, according to the method described by Satoh [30]. Lung superoxide dismutase (SOD) activity was estimated by colorimetric method using superoxide dismutase assay kit purchased from Biodiagnostic Co., Egypt, following to the method described by Nishikimi et al. [31]. Lung catalase (CAT) activity was determined by colorimetric method using catalase assay kit purchased from Biodiagnostic Co., Egypt, according to the method described by Aebi [32]. Lung glutathione peroxidase (GSH-Px) activity was assayed by spectrophotometric method using glutathione peroxidase assay kit purchased from Biodiagnostic Co., Egypt, according to the method of Paglia and Valentine [33]. Total antioxidant capacity (TAC) was measured according to the method of koracevic et al. [34], using EIA kit that was purchased from Labor Diagnostika Nord Co., Germany.

\section{Histological techniques}

Different pieces from the left and right lung lobes were collected and processed for general histological stain and masson trichrome. This technique was done according to Bancroft and Stevens [35].

\section{Immunohistochemical techniques}

Sections were deparaffinized in xylene and rehydrated through graded concentrations of ethanol. Incubated in antigen retrieval buffer (boiling the sections at $98^{\circ} \mathrm{C}$ for $20 \mathrm{~min}$ in $10 \mathrm{mmol} / \mathrm{L}$ sodium citrate buffer), treated with $3 \% \mathrm{H} 2 \mathrm{O} 2$ to block endogenous peroxidase. The slides were allowed to cool to room temperature. The sections were further incubated with the primary antibody against bax (Mouse monoclonal, Clone 2D2, Neomarkers, USA), bcl-2 (Mouse monoclonal Clone 8C8, Neomarkers, USA), ki67 (monoclonal antibody, DAKO Corp.) were applied for 30 minutes. Biotinylated polyvalent secondary antibody (Cat. No. 32230, Thermo Scientific Co., UK) was applied to tissue sections and co-incubated for $30 \mathrm{~min}$. The slides were washed three times for $3 \mathrm{~min}$ each with wash buffer. The reaction was visualized by adding Metal Enhanced DAB Substrate Working Solution to the tissue and incubated $10 \mathrm{~min}$. Finally all sections were counterstained with Mayer's hematoxylin [36].

\section{Statistical analysis}

Results are expressed as means \pm SEM of 10 different rats per each group. Statistical analysis was done using ANOVA and Fisher's post hoc test, with $\mathrm{p}<0.05$ being considered as statistically significant.

\section{Results}

\section{Biochemical analyses}

The data in Table 1 showed the effect of grape seed extract on lung level of pro-oxidant markers and antioxidant enzymes in $\mathrm{Cd}$ challenged rats. The present data revealed that administration of $\mathrm{Cd}$ induced oxidative stress that manifested by a significant increase in lipid peroxidation product MDA in lung with respect to control group. Meanwhile, marked depletion in tissue levels of CAT, SOD and GPx 
activity as well as serum TAC was observed in Cd administered rats as compared to control ones. However, the groups of rats treated with grape seed significantly attenuated oxidative stress by reducing lung tissue MDA and improving Gpx content as well as antioxidant enzymes activities in lung tissues and serum TAC in comparison to group II.

\begin{tabular}{|l|l|l|l|l|}
\hline Parameter & Control & Cd & GSE & Cd + GSE \\
\hline $\begin{array}{l}\text { MDA(nmol/mg } \\
\text { protein) }\end{array}$ & $3.1 \pm .13$ & $8.6 \pm 0.29 \mathrm{a}$ & $2.9 \pm 0.07$ & $4.5 \pm 0.17 \mathrm{~b}$ \\
\hline $\begin{array}{l}\text { CAT(U/mg } \\
\text { protein) }\end{array}$ & $6.13 \pm 0.94$ & $4.15 \pm 0.67 \mathrm{a}$ & $5.81 \pm 0.36$ & $5.64 \pm 0.34 \mathrm{~b}$ \\
\hline $\begin{array}{l}\text { SOD(U/mg } \\
\text { protein) }\end{array}$ & $3.36 \pm 0.89$ & $2.24 \pm 0.67 \mathrm{a}$ & $3.24 \pm 0.79$ & $3.05 \pm 0.71 \mathrm{~b}$ \\
\hline $\begin{array}{l}\text { GPx(U/mg } \\
\text { protein) }\end{array}$ & $91.6 \pm 1.68$ & $47.4 \pm 1.11 \mathrm{a}$ & $89.4 \pm 1.29$ & $74.4 \pm 1.57 \mathrm{~b}$ \\
\hline TAC( $\mu \mathrm{mol} / \mathrm{L})$ & $0.79 \pm 0.05$ & $0.05 \pm 0.02 \mathrm{a}$ & $0.75 \pm 0.06$ & $0.55 \pm 0.08 \mathrm{~b}$ \\
\hline
\end{tabular}

Table 1: Effect of grape seed extract (GSE) on pro-oxidant markers and antioxidant enzymes levels in lung of Cd challenged rats. Results are expressed as mean \pm SD for 10 rats/group. a: Value significantly different from control group $(\mathrm{p}<0.05)$. b: Value significantly different from Cd group $(\mathrm{p}<0.05)$. MDA: malondialdehyde; CAT: catalase; SOD: superoxide dismutase; GPx: glutathione peroxidase; TAC: total antioxidant capacity.

\section{Histopathology and immunohistochemistry}

The lung tissue of the control group consisted of bronchioles; primary, secondary and terminal bronchioles and alveoli. The alveoli lined by alveolar cells and connected together by inter-alveolar septum. The alveolar duct was lined by cuboidal epithelium while the alveolar sac consisted of 3-4 alveoli (Figure 1A-1C).

Positive immunohistochemical staining for bcl-2 was demonstrated in the cells of the lung tissue (Figure 1D). Positive immunohistochemical staining for bax was demonstrated in the cells of the alveoli and lining epithelium of the secondary bronchiole (Figure 1E). Positive immunohistochemical staining for ki67 was demonstrated in single cells of the lining epithelium of the alveoli (Figure 1F).

The lung tissue of the second group showed thickened interalveolar septum with sparsely infiltrated lymphocytic cells. The blood vessels were congested and edematous. Fibrous CT was increased around the wall of the bronchioles with hyperplasia of the lining cells. Diffuse and circumscribed areas of lymphocytic infiltration were spread between the lung tissue (Figure 2A-2C). Negative immunostaining for Bcl-2 (Figure 2D). Strong immunostaining reactions were detected in the lung cells for bax and ki67 (Figure 2E and 2F).

The lung tissue of the third group showed the same histological structure as that of the first control group (Figure 3A). Positive immunostainig for bcl-2 (Figure 3B) and weak immunostainig for bax and ki67 (Figure 3C and 3D).

The lung tissue of the fourth group showed some patches of the lung tissue still consisted of thickened interalveolar septum and edematous blood vessels (Figure 4A) and circumscribed areas of lymphocytic infiltration (Figure 4B). Most of the lung tissue showed normal structure as that of the control group except some blood vessels showed congestion (Figure 4C). Some cells of the alveolar tissue showed positive immunostaing for bcl-2 (Figure 4D), while few cells showed positive immunostaining reaction for bax and ki67 (Figure $4 \mathrm{E}$ and $4 \mathrm{~F})$.

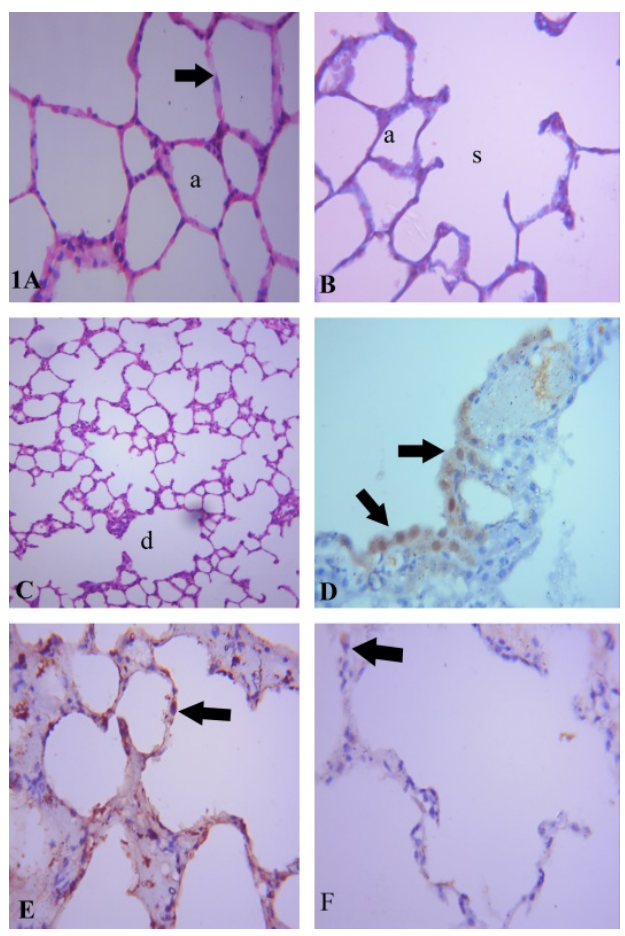

Figure 1: Photomicrographs of the male albino rats lung of the control group showing in (A), the alveoli (a) and interalveolar septum (arrow) H\&E X400. In (B), the alveolar sac (s) and the alveoli (a) Masson trichrome X400. In (C), the alveolar duct (d) H\&E X100. In (D), immunostaining for bcl-2 (arrows) X400. In (E), positive immunostaining for bax (arrow) X400. In (F), positive immunostaining for ki67 (arrow) X400.

\section{Discussion}

Due to the progress in industry and agricultural activities, the people who lived adjacent to these cities are mostly subjected to pneumonia, digestive disorders including diarrhea, stomach pains and possibly DNA damage or cancer development [37]. Cd accumulates and is proved to cause severe damages to a variety of organs such as lung, brain, testis, kidney, liver and circulatory system [5]. In the present work, Cd led to the production of free radicals, as reported by Stohs and Bagchi [38], who showed that cadmium toxicity led to generation of free radicals, which led to oxidative deterioration of lipids, proteins, DNA, activation of procarcinogens, inhibition of cellular and antioxidant defense systems.

The results of this study showed that the lung tissue of the Cd group exhibited thickened interalveolar septum with sparsely infiltrated lymphocytic and fibrous CT was increased around the wall of the 
bronchioles with hyperplasia of the lining cells, in consonance with Kundu et al. [39], El-Sokkary and Awadalla [40], Shin et al. [41], ElRefaiy and Eissa [42] and Ahmed et al. [43]. These studies found that the chronic exposure of cadmium compound induces lung cell proliferation which may be independent of lung inflammation, edema and congestion are sincere results of vascular system inflammation of the lung and bronchioles.

Diffuse and circumscribed lymphocytic infiltration in the lung tissue of the Cd group then the severity decreased in the fourth group. These results were conforming to results of Yamada et al. [44], Driscoll et al. [45], Bell et al. [46], El-Refaiy and Eissa [42] and Ahmed et al. [43].
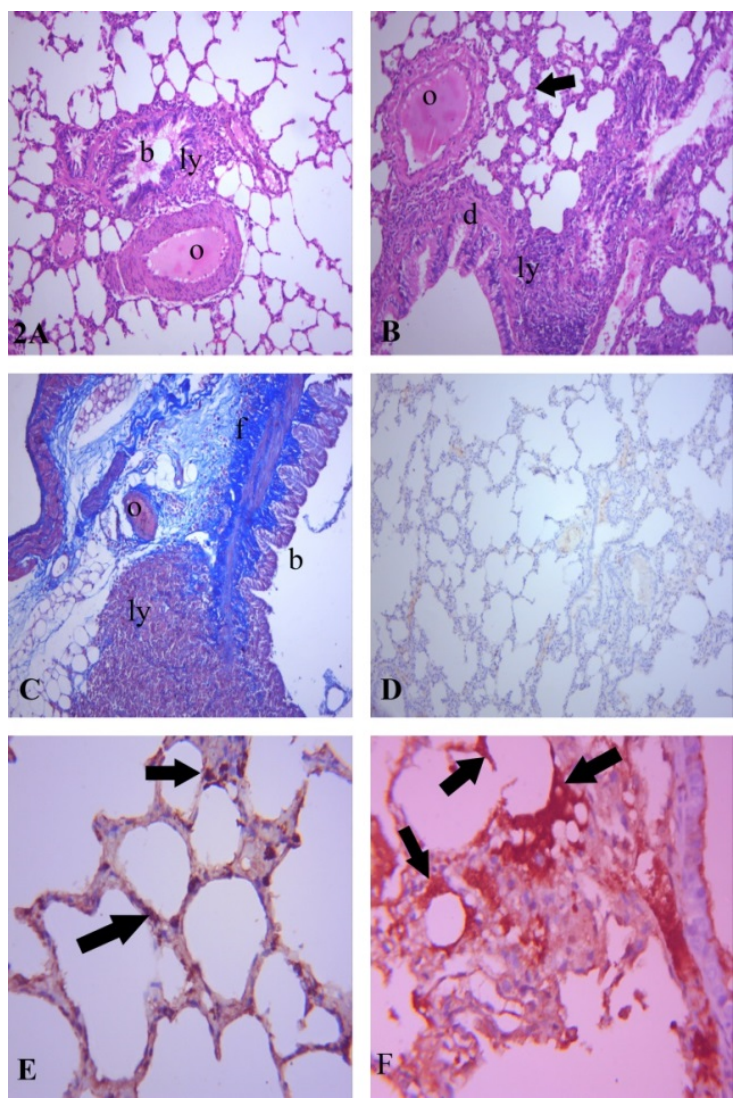

Figure 2: Photomicrographs of the male albino rats lung of the $\mathrm{Cd}$ group showing in (A), the lymphocytic infiltrations (ly) around the bronchioles (b) and edematous blood vessels (o) H\&E X400. In (B), thickening in the interalveolar septum (arrow), degeneration of the bronchioles epithelium (d), lymphocytic infiltration (ly) and edematous blood vessels (o) H\&E X400. In (C),increased fibrous Ct (f) around the bronchioles (b) with lymphocytic infiltrations (ly) and edematous blood vessels (o) Masson trichrome X400. In (D), negative immunostaining for bcl-2 X400. In (E), positive immunostaining for bax (arrows) X400. In (F), positive immunostaining for ki67 (arrows) X400.

Grapes are considered as one of the most widely eats up fruits. The grape seed proanthocyanidins (GSPs) have killing effect on the tumor cells without hurting the normal cells [47].
In the present study, the rats groups treated with grape seed significantly diminished oxidative stress by reducing lung tissue MDA and improving antioxidant enzymes activities in lung tissues and serum TAC, this is confirmed by findings of Cheng et al. [48], Li et al [49].

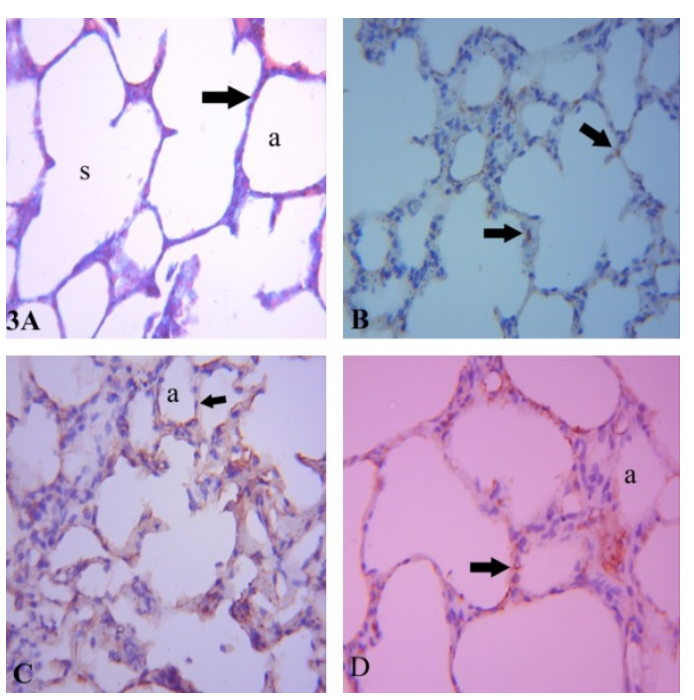

Figure 3: Photomicrographs of the male albino rats lung of the third group showing in (A), the alveoli (a) and interalveolar septum (arrow) and alveolar sac (s) Masson trichrome X400. In (B), positive immunostaining for bcl-2 (arrows) X400. In (C), weak immunostaining for bax X400. In (D), weak immunostaining for ki67 (arrow) X400.

and Ahmed et al. [43], who showed that GSE has antioxidant, antiinflammatory and antitumor activities, and to mediate resistance to free radicals. GSE is a powerful free radical scavenger [50-52]. These findings were in accordance with our results and support it in the same way.

Grape seeds have phenolic acids and flavonoids [53]. Lago et al. [54] reported that the anti-inflammatory effects of phenolic compounds are related to their ability to regulate the expression of pro-inflammatory genes, such as cyclooxygenase, lipoxygenase and also by acting around NF- $\kappa B$ signaling and MAPK [55]. Flavonoids exert their antiinflammatory effects by regulating the inflammatory cells, suppress the $\mathrm{T}$ lymphocyte proliferation, inhibiting pro-inflammatory cytokines [56].

The anti-apoptotic protein Bcl-2 has been associated with inhibition of apoptosis whereas the increased expression of the pro-apoptotic protein, Bax, has been associated with the induction of apoptosis $[57,58]$. These findings were in accordance with our results and support it in the same way. GSE has a powerful cytotoxicity towards breast cancer, lung and gastric adenocarcinoma cells, while enhancing the growth and viability of normal cells [47]. It has been recognized that intracellular movement of pro-apoptotic proteins, such as Bax, depolarizes mitochondria and induces the release of cytochrome $c$ through openings in the outer membrane formed as a consequence of permeability transition and loss of mitochondrial membrane potential 
Page 5 of 7

[59]. The antiapoptotic effects of GSE in various tissues, including reduction of apoptotic cell death and

suppression of proapoptotic proteins $[27-29,60]$. So these findings are in concordance with our results, where the level of Bcl-2 was increased while levels of Bax and Ki67 were decreased in the lung cells groups treated by GSE compared to group II.
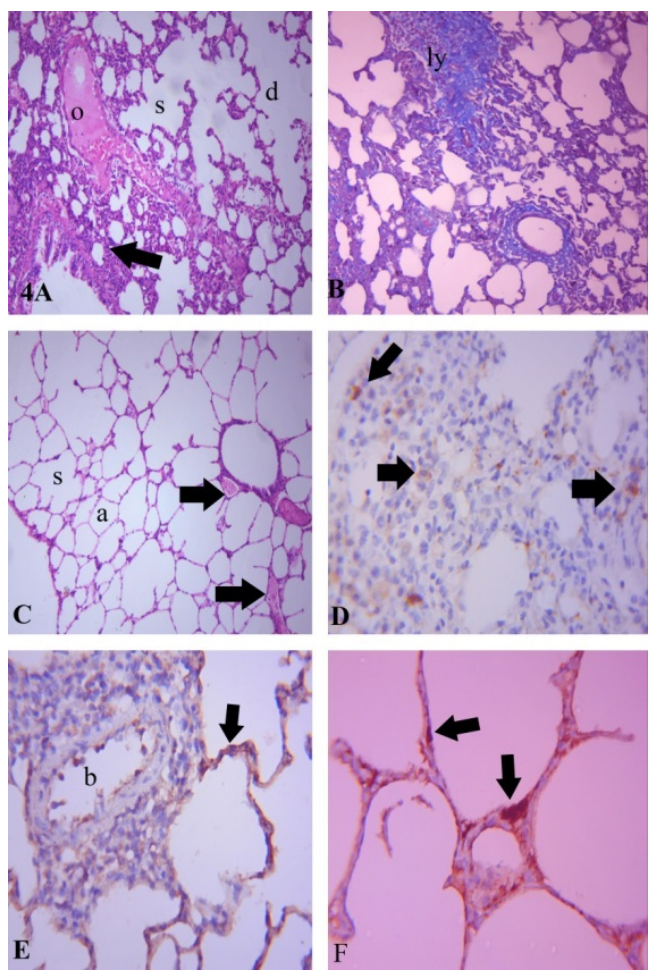

Figure 4: Photomicrographs of the male albino rats lung of the fourth group showing in (A), the edematous blood vessels (o), alveolar duct (d), alveolar sac (s) in normal areas with thickening in the interalveolar septum (arrow) H\&E X400. In (B), lymphocytic infiltration still persist around the bronchioles (ly) Masson trichrome X400. In (C), nearly the whole lung tissue back to normal structure although some blood vessles still congested (arrow). H\&E X100. In (D), positive immunostaining for bcl-2 (arrows) X400. In (E), few positive immunostaining for bax (arrow) around the bronchioles (b) X400. In (F), few positive immunostaining for ki67 (arrows) X400.

\section{Conclusion}

In summary, the addition of grape seeds extract improves the hazard toxic effect against lung injury induced by cadmium chloride, include powerful free radical scavenging property, strong antioxidant activity by reducing lung tissue MDA and improving antioxidant enzymes activities in lung tissues and serum TAC, potent antiinflammatory capacity and effective anti-apoptotic potential in lung tissue where the level of Bcl-2 was increased while levels of Bax and Ki67 were decreased in the lung cells groups treated with GSE.

\section{Acknowledgments}

The author appreciates Dr. Mohamed M Soliman, Medical Laboratory Department, Taif University for providing facilities for Biochemical Analyses.

\section{References}

1. Sherlock JC (1984) Cadmium in foods and the diet. Experientia 40: $152-56$.

2. Sarwar N, Malhi SS, Zia MH, Naeem A, Bibi S, et al. (2010) Role of mineral nutrition in minimizing cadmium accumulation by plants. Journal of the Science of Food and Agriculture 90: 925-937.

3. Satarug S, Moore MR (2004) Adverse health effects of chronic exposure to low-level cadmium in foodstuffs and cigarette smoke. Environmental Health Perspectives 112: 1099-1103.

4. Manca D, Ricard AC, Trottier B, Chevalier G (1991) Studies on lipid peroxidation in rat tissues following administration of low and moderate doses of cadmium chloride. Toxicology 67: 303-323.

5. Ercal N, Gurer-Orhan H, Aykin-Burns N (2001) Toxic metals and oxidative stress Part 1: Mechanisms involved in metal-induced oxidative damage. Current Topics in Medicinal Chemistry 1: 529-39.

6. Luchese C, Pinton S, Nogueira WC (2009) Brain and lungs of rats are differently affected by cigarette smoke exposure: antioxidant effect of an organoselenium compound. Pharmacological Research 59: 194-201.

7. Liu J, Shen HM, Ong CN (2001) Role of intracellular thio depletion, mitochondrial dysfunction and reactive oxygen species in Salvia miltiorrhiza-induced apoptosis in human hepatoma HepG2 cells. Life Sciences 69: 1833-1850.

8. Stohs SJ, Bagchi D, Hassoun E, Bagchi M (2000) Oxidative mechanisms in the toxicity of chromium and cadmium ions. Journal of Environmental Pathology, Toxicology and Oncology 19: 201-213.

9. Thevenod F (2003) Nephrotoxicity and the proximal tubule insights from cadmium. Nephron Physiology 93: 87-93.

10. Lag M, Westly S, Lerstad T, Bjornsrud C, Refsnes M, et al. (2002) Cadmium-induced apoptosis of primary epithelial lung cells: Involvement of bax and p53, but not of oxidative stress. Cell Biology and Toxicology 18: 29-42.

11. Templeton N, Lewis A, Dorai H, Qian EA, Campbell MP, et al. (2014) The impact of anti-apoptotic gene $\mathrm{Bcl}-2 \Delta$ expression on $\mathrm{CHO}$ central metabolism. Metabolic Engineering 25: 92-102.

12. Joseph P (2009) Mechanisms of cadmium carcinogenesis. Toxicology and Applied Pharmacology 238: 272-9.

13. Zhang X, Barile G, Chang S, Hays A, Sparrow J, et al. (2005) Apoptosis and cell proliferation in proliferative retinal disorders: PCNA, Ki-67, caspase-3, and PARP expression. Current Eye Research 30: 395-403.

14. Abd El Kader MA, El-Sammad NM, Fyiad AA (2011) Effect of grape seeds extract in the modulation of matrix metalloproteinase-9 activity and oxidative stress induced by doxorubicin in mice. Life Science Journal 8: 510-515.

15. Ahmed AAE, Fatani AJ (2007) Protective effect of grape seeds proanthocyanidins against naphthalene-induced hepatotoxicity in rats. Saudi Pharmaceutical Journal 15: 38-47.

16. Raina K, Singh RP, Agarwal R, Agarwal C (2007) Oral grape seed extract inhibits prostate tumor growth and progression in TRAMP mice. Cancer Research 67: 5976-5982.

17. Bagchi D, Bagchi M, Stohs S, Das D, Ray S, et al. (2000) Free radicals and grape seed proanthocyanidin extract: importance in human health and disease prevention. Toxicology 148: 187-197.

18. Jovanovic SV, Steenken S, Tosic M, Marjanovic B, Simic MG (1994) Flavonoids as antioxidants. Journal of American Chememistry Society 116: 4846-4851.

19. Rice-Evans CA, Miller NJ, Paganda G (1996) Structure antioxidant activity relationships of flavonoids and phenolic acids. Free Radical Biology and Medicine 20: 933-956. 
20. Lim G, Jang S, Song KB (2010) Physical and Antimicrobial Properties of Gelidium corneum/nano-clay Composite Film Containing Grapefruit Seed Extract or thymol. Journal of Food Engineering 98: 415-420.

21. Saito M, Hosoyama H, Ariga T, Kataoka S, Yamaji N (1998) Antiulcer Activity of Grape Seed Extract and Procyanidins. Journal of Agricultural and Food Chemistry 46: 1460-1464.

22. Aloui H, Khwaldia K, Sánchez-González L, Muneret L, Jeandel C, et al. (2014) Alginate Coatings Containing Grapefruit Essential Oil or Grapefruit Seed Extract for Grapes Preservation. International Journal of Food Science and Technology 49: 952-959.

23. Ashtiyani S, Najafi H, Firouzifar M, Shafaat O (2013) Grape seed extract for reduction of renal disturbances following reperfusion in rats. Iranian Journal of Kidney Disease 7: 28-35.

24. Terra X, Montagut G, Bustos M, Llopiz N, Ardèvol A, et al. (2009) Grapeseed procyanidins prevent low-grade inflammation by modulating cytokine expression in rats fed a high-fat diet. Journal of Nutritional Biochemistry 20: 210-218.

25. Kaur M, Singh RP, Gu M, Agarwal R, Agarwal C (2006) Grape seed extract inhibits in vitro and in vivo growth of human colorectal carcinoma cells. Clinical Cancer Research 12: 6194-6202.

26. Madkour NK, Ahmed M (2013) Amelioration of amiodarone-induced lung fibrosis in rats by grape seed extract. Journal of Applied Sciences Research 9: 3698-3707.

27. Ozkan G, Ulusoy S, Alkanat M, Orem A, Akcan B, et al. (2012) Antiapoptotic and antioxidant effects of GSPE in preventing cyclosporine Ainduced cardiotoxicity. Renal Failure 34: 460-466.

28. Bayatli F, Akkuş D, Kilic E, Saraymen R, Sönmez MF (2013) The protective effects of grape seed extract on MDA, AOPP, apoptosis and eNOS expression in testicular torsion: an experimental study. World Journal of Urology 31: 615-622.

29. Chen Q, Zhang R, Li WM, Niu YI, Guo HC, et al. (2013) The protective effect of grape seed procyanidin extract against cadmiuminduced renal oxidative damage in mice. Environmental Toxicology and Pharmacology 36: 759-768.

30. Satoh K (1978) Serum lipid peroxide in cerebrovascular disorders determined by a new colorimetric method. Clinica Chimica Acta 90: $37-43$.

31. Nishikimi M, Appaji N, Yagi K (1972) The occurrence of superoxide anion in the reaction of reduced phenazine methosulfate and molecular oxygen. Biochemical and Biophysical Research Communications 46: 849-854.

32. Aebi H (1984) Catalase in vitro. Methods in Enzymology 105: 121-6.

33. Paglia DE, Valentine WN (1967) Studies on the quantitative and qualitative characterization of erythrocyte glutathione peroxidase. Journal of Laboratory and Clinical Medicine 70: 158-169.

34. Koracevic D, Koracevic G, Djordjevic V, Andrejevic S, Cosic V (2001) Method for the measurement of antioxidant activity in human fluids. Journal of Clinical Pathology 54: 356-361.

35. Bancroft JD, Stevens A (2002) Theory and Practice of Histological Technique: 4th Edition. Journal of Pathology 183: 243-244.

36. Kiernan JA (2008) Histological and Histochemical Methods-Theory and Practice: 4th Edition. Bloxham, Scion, Cold Spring Harbor Laboratory Press.

37. Singh P, Chaudhary S, Patni A, Sankhla V (2007) Effect of cadmium chloride induced genotoxicity in bone marrow chromosomes of swiss albino mice and subsequent protective effects of Emblica officinalis and vitamin C. Journal of Herbal Medicine and Toxicology 1: 67-71.

38. Stohs SJ, Bagchi D (1995) Oxidative mechanisms in the toxicity of metal ions. Free Radical Biology and Medicine 18: 321-336.

39. Kundu S, Sengupta S, Chatterjee S, Mitra, S, Bhattacharyya A (2009) Cadmium induces lung inflammation independent of lung cell proliferation: a molecular approach. Journal of Inflammation 12: 6-19.

40. El-Sokkary GH, Awadalla EA (2011) The protective role of vitamin C against cerebral and pulmonary damage induced by cadmium chloride in male adult albino rat. The Open Neuroendocrinology Journal 4: 1-8.
41. Shin HJ, Lee BH, Yeo MG, Oh SH, Park JD, et al. (2004) Induction of orphan nuclear receptor Nur77 gene expression and its role in cadmiuminduced apoptosis in lung. Carcinogenesis 25: 1467-1475.

42. El-Refaiy AI, Eissa FI (2013) Histopathology and cytotoxicity as biomarkers in treated rats with cadmium and some therapeutic agents. Saudi Journal of Biological Sciences 20: 265-280.

43. Ahmed HH, Abd-El-Dayem SM, Metwally FM, Foad NM (2015) Biological significance of grape seed extract against lung injury induced by formaldehyde inhalation in rats. Der Pharma Chemica 7: 64-78.

44. Yamada H, Damiano VV, Meranze DR, Glasgow J, Abrams WR, et al. (1982) Neutrophil degranulation in cadmium chloride induced acute lung inflammation. The American Journal of Pathology 109: 145-156.

45. Driscoll KE, Maurer JK, Poynter J, Higgins J, Asquith T, et al. (1992) Stimulation of rat alveolar macrophage fibronectin release in a cadmium chloride model of lung injury and fibrosis. Toxicology and Applied Pharmacology 116: 30-37.

46. Bell RR, Nonavinakere VK, Soliman MR (2000) Intratracheal exposure of the guinea pig lung to cadmium and/or selenium: a histological evaluation. Toxicology Letters 114: 101-109.

47. Ye X, Krohn RL, Liu W, Joshi SS, Kuszynski CA, et al. (1999) The cytotoxic effects of a novel IH636 grape seed proanthocyanidin extract on cultured human cancer cells. Molecular and Cellular Biochemistry 196: 99-108.

48. Cheng M, Gao HQ, Xu L, Li BY, Zhang H, et al. (2007) Cardioprotective effects of grape seed proanthocyanidins extracts in streptozocin induced diabetic rats. J Cardiovascular Pharmacology 50: 503-509.

49. Li X, Xiao Y, Gao H, Li B, Xu L, et al. (2009) Grape seed proanthocyanidins ameliorate diabetic nephropathy via modulation of levels of AGE, RAGE and CTGF. Nephron Experimental Nephrology 111: e31-41.

50. Balu M, Sangeetha P, Murali G, Panneerselvam C (2006) Modulatory role of grape seed extract on age-related oxidative DNA damage in central nervous system of rats. Brain Research Bulletin 68: 469-473.

51. Devi A, Jolitha Ab, Ishii N (2006) Grape seed proanthocyanidin extract (GSPE) and antioxidant defense in the brain of adult rats. Medical Science Monitor 12: 124-129.

52. Lu M, Xu L, Li B, Zhang W, Zhang C, et al. (2010) Protective effects of grape seed proanthocyanidin extracts on cerebral cortex of streptozotocin-induced diabetic rats through modulating AGEs/ RAGE/NF-kappaB pathway. Journal of Nutritional Science and Vitaminology 56: 87-97.

53. Yilmaz Y, Toledo RT (2006) Oxygen radical absorbance capacities of grape/wine industry by products and effect of solvent type on extraction of grape seed polyphenols. Journal of Food Composition and Analysis 19: 41-48.

54. Lago JH, Toledo-Arruda AC, Mernak M, Barrosa KH, Martins MA, et al. (2014) Structure-Activity Association of Flavonoids in Lung Diseases. Molecules 19: 3570-3595.

55. Toledo AC, Sakoda CP, Perini A, Pinheiro NM, Magalhaes RM, et al. (2013) Flavonone treatment reverses airway inflammation and remodelling in an asthma murine model. British Journal of Pharmacology 168: 1736-1749.

56. Lopez-Posadas R, Ballester I, Abadia-Molina AC, Suarez MD, Zarzuelo A et al. (2008) Effect of flavonoids on rat splenocytes, a structure-activity relationship study. Biochemical Pharmacology 76: 495-506.

57. Oltvai ZN, Milliman CL, Korsmeyer SJ (1993) Bcl-2 heterodimerizes in vivo with a conserved homolog, Bax, that accelerates programmed cell death. Cell 74: 609-619.

58. Zhan Q, Fan S, Bae I, Guillouf C, Liebermann DA, et al. (1994) Induction of Bax by genotoxic stress in human cells correlates with normal p53 status and apoptosis. Oncogene 9: 3743-3751.

59. Green DR, Reed JC (1998) Mitochondria and Apoptosis. Science 281: 1309-1312. 
Citation: Baiomy AA (2016) Protective Role of Grape Seeds Extract against Cadmium Toxicity in the Lung of Male Wistar Rats. J Cytol Histol S5: 004. doi:10.4172/2157-7099.S5-004

60. Cedó L, Castell-Auví A, Pallarès V, Blay M, Ardévol A, et al. (2013) Grape seed procyanidin extract modulates proliferation and apoptosis of pancreatic betacells. Food Chemistry 138: 524-530.

This article was originally published in a special issue, entitled: "Fine Needle Aspiration Cytology in Disease Diagnosis", Edited by Borislav A. Alexiev 